\title{
After the Indian Ocean Tsunami (IOT): Natural beach recovery, Meulaboh, Sumatra, Indonesia
}

\author{
Lucy Buck $^{1 *}$, Charlie Bristow ${ }^{1}$, Ella Meilianda $^{2}$ \\ ${ }^{1}$ Earth and Planetary Science Department, Birbeck, University of London, Malet Street, London, WC1E7HX, England \\ ${ }^{2}$ Civil Engineering Department, Engineering Faculty, Universitas Syiah Kuala, Jalan Tgk. Abdur Rauf, Kopelma Darussalam, Banda \\ Aceh, 23111, Indonesia
}

\begin{abstract}
Ground-penetrating radar (GPR) offers an efficient and non-invasive method of identifying and characterising subsurface features. It has previously been used to investigate both tsunami deposits and marine erosion surfaces from tsunamis as well as the structure of the structure of prograding beaches. The present study investigates beach deposits at Meulaboh, western coast of Aceh Province in Sumatra Island of Indonesia, to estimate the volume of sediment that has been deposited since the 2004 Indian Ocean Tsunami, using the GPR with an antenna of $200 \mathrm{MHz}$. Two profiles perpendicular to the coastline were collected, one $93 \mathrm{~m}$ long and the other $30 \mathrm{~m}$ long, to capture the internal profile of beach ridge deposition. From the GPR measurement the amount of 1,190,191,716 tons of sediment redeposited along the $1092 \mathrm{~m}$ coastline since the 2004 tsunami, with a prograding length of $73 \mathrm{~m}$ per year. As beaches provide a good form of tsunami protection the rapid beach recovery and the return of a large amount of sediment helps provide much needed coastal protection to the area.
\end{abstract}

\section{Introduction}

On 26" December 2004 a 9.3 earthquake struck off the coast of Sumatra. The epicentre was located $80 \mathrm{~km}$ west of the coast of northern Sumatra $\left(95.51 ' 0 \mathrm{~W}, 3 \cdot 25^{\prime} 0 \mathrm{~N}\right)$ [9] at a depth of $25-30 \mathrm{~km} \mathrm{[6].} \mathrm{The} \mathrm{resulting} \mathrm{tsunami}$ was the most devastating tsunami in recorded history and caused more than 292,000 fatalities in 12 countries [9] with over 1 million left homeless [6].

In Sumatra, the resulting Indian Ocean Tsunami (IOT) consisted of three main waves and a retreat of the sea was observed 10 minutes after the earthquake, the first wave arrived 3 minutes later, the second and largest wave arrived within 5 minutes of the first wave, there are few observations for the third wave however the return flow was achieved 5 minutes after the third wave [21]. A $51 \mathrm{~m}$ run up was recorded in Lho Nga [22].

Meulaboh is a city $181 \mathrm{~km}$ south of Banda Aceh, on the west side of the Island of Sumatra. The study site is $14 \mathrm{~km}$ north of the city on a long, straight part of the NW-SE trending coast, midway between the Bhee river and the headland. The tsunami damaged almost all structures, including the airport, roads, both jetties and a hospital, along the coast and flooded up to $2 \mathrm{~km}$ inland [13], reaching wave heights of $9-14 \mathrm{~m}$ and reached 2$2.5 \mathrm{~km}$ inland [14]. The coast is relatively low-lying and the beach is backed by a sequence of ridges and swales with the tsunami deposits locally preserved in the marshy swales. Previous work by Monecke et al [14] identified tsunami deposits from the 2004 event as well as tsunamis dating to $1290-1400$ and $780-990$ here. The oldest tsunami deposits are found in the swale furthest from the current beach, approximately $1,800 \mathrm{~m}$ from the coastline [14].

The tsunami caused widespread erosion along the coast of Sumatra, including the removal of all depositional features such as beaches, low sand dunes and wetlands [15]. However, within weeks deposition features started to reform. The post-tsunami coast undergoes the same coastal processes as the pre tsunami coast. As a results new coastal features formed within the same constraints and the present coast closely resembles the pre tsunami coast [15]. Due to this Liew et al. [15] suggest that sedimentary deposits are a better indication of past tsunamis than coastal morphology.

Ground-penetrating radar (GPR) offers an efficient and non-invasive method of identifying and characterising subsurface features $[10,18]$. It has previously been used to investigate both tsunami deposits [5] and marine erosion surfaces from tsunamis [23] as well as the structure of the structure of prograding beaches $[2.4,17,19-20,24]$.

In this study we use GPR to investigate the beach deposits at Meulaboh and estimate the volume of sediment that has been deposited since the 2004 Indian Ocean Tsunami.

\section{Methods}

A GPR survey was conducted in September 2019. Two profiles were collected, one $93 \mathrm{~m}$ long and the other 30 $\mathrm{m}$ long. The profiles were perpendicular to the coast and the locations can be seen in figure 1.3. An antenna frequency of $200 \mathrm{MHz}$ was used with a step size of 0.5

\footnotetext{
* Corresponding author: lucy.buck.15@ucl.ac.uk
} 
$\mathrm{m}$ and a separation of $1 \mathrm{~m}$. Topographic data was collected using levelling techniques.

The data was processed using EKKO Project 5. The data underwent a Dewow, SEC2 Gain and a FK migration using velocity of $0.07 / \mathrm{s}$. The sediment volume that has built up since the 2004 tsunami was evaluated using polygons with the lower boundary being the erosional layer created by the tsunami and the upper boundary being the surface. The area of this polygon was used to calculate the area of sediment that had accumulated since the tsunami. To calculate the volume the length of the erosional ridge along this part of the coast was used.

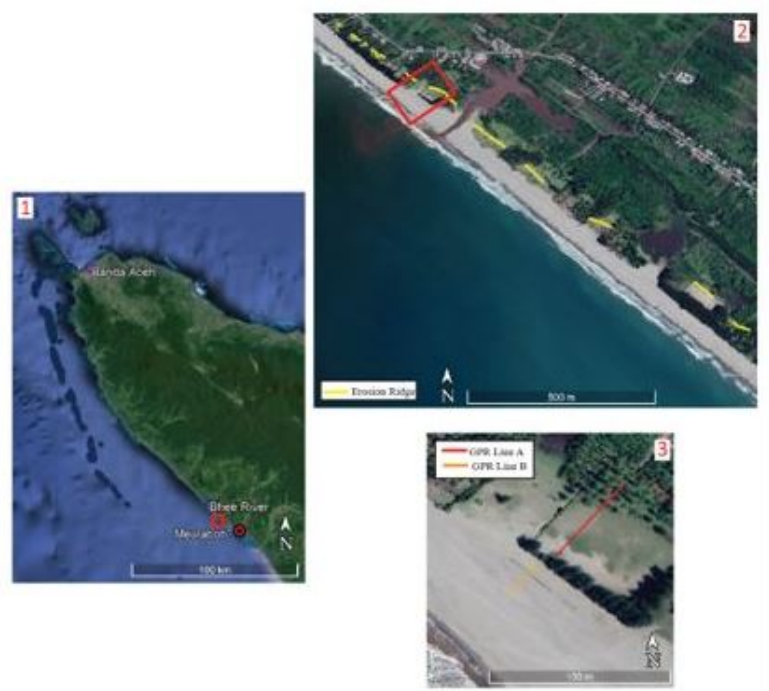

Fig.1. 1) Sattellite image showing Aceh and the location of Banda Aceh, the location of image B is shown by the red box. 2) The coast north of Meulaboh showing the erosional ridge in yellow, the location of image $C$ is shown by the red box. 3 ) The location of the two GPR profiles used in this survey. Line A starts just beyond the erosional ridge, line $\mathrm{B}$ ends by the sand cliff at the high tide line. (Source: Google Earth).

\section{Result}

The GPR data for line A can be seen in figure 2 and is shown with both a depth and time scale. The GPR profile shows several reflections with a strong amplitude. There are multiple inclined reflections, in orange, that dip from left to right, that is towards the sea. In addition, there are concave reflections that are between $15 \mathrm{~m}$ and $40 \mathrm{~m}$ wide and, with one exception, start at the surface and reach $9 \mathrm{~m}$ deep across the entire the profile. The inclined reflections that dip towards the sea are interpreted as beach progrades with each reflection marking a former position of the beach.

Due to its correspondence with the ridge that marks the scarp formed by the 2004 IOT the reflection marked in blue is interpreted to be the tsunami erosion surface. The concave reflections, shown in brown, are interpreted as erosion surfaces either formed by earlier coastal erosion, or the river that runs parallel to the coast behind the beach. Prior to the tsunami the coconut palm trees extended much further toward the sea at the time of study the trees were over 15 years old, the age of the tsunami, and were only present inland from the ridge, further reinforcing the idea that the ridge and erosional surface were created by the tsunami.

If the erosional surface is extrapolated to the sea the volume of sand above that line represents the sediment that has been added to the beach since the 2004 tsunami. Along this single profile this has been calculated to be $329 \mathrm{~m}^{2}$. The beach ridge has been measured to be 1902 $\mathrm{m}$ long. If the sediment volume in the GPR is multiplied along the length of the beach ridge then $625,758 \mathrm{~m}^{3}$ or $1,190,191,716$ tons of sediment, has been returned to the beach since the tsunami, assuming a bulk density of 1.6 $\mathrm{g} / \mathrm{cm} 3$ for beach sand. To put this in context, an Olympic swimming pool has a volume of $2,500 \mathrm{~m}^{3}$, so that is equivalent to 250 Olympic swimming pools of sand. This amount of sand would take 38,263 standard 25 tons dumper trucks to move. Using the ridge as the erosional limit the beach has grown in length by $177 \mathrm{~m}$ between 2004 and 2019 giving a horizontal rate of progradation of $7.3 \mathrm{~m}$ per year.

\section{Discussion}

The rapid recovery of the beach north of Meulaboh documented here is consistent with observations of post tsunami beach recovery after the 2011 Tohoku Tsunami in Japan [8] and at Lampu Uk, the bay immediately north to Leupung $60 \%$ of the sediment lost due to the tsunami was regained within 6 months [16]. This rapid beach recovery has also been seen in Thailand after the 2004 IOT $[3,7,11]$. The implication is that sediment eroded from the beach by the tsunami has remained close to the coast so that it was available to be transported back onshore under normal wave conditions.

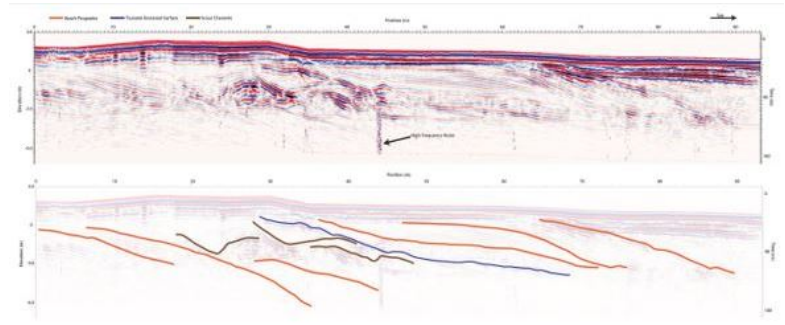

Fig. 2. GPR data from line A, this is the longer profile that was taken further inland. The top image shows the uninterpretated but processed data, the below image shows the interpretations used here. The tsunami erosional surface is shown in blue, the beach progrades are shown in orange and the paleochannels in brown. The data is presented with an elevation scale on the left and a velocity scale on the right. For all relevant processing a velocity of $0.07 \mathrm{~m} / \mathrm{s}$ was used. The sea is to the right of the figure.

The natural restoration of the beach in less than 20 years has implications for shoreline management on tsunami prone coasts. Construction of artificial sea defenses immediately after a tsunami event, and artificial beach nourishment may not be required if the beach will restore itself [12]. It would also be advisable to restrict development within the areas that have recovered to provide a buffer against potential tsunami erosion in the future $[11,15]$. 


\section{Conclusion}

Meilianda et al. found that at Lampu Uk, the bay immediately north to Leupung, $60 \%$ of the sediment lost due to the tsunami was regained within 6 months [16]. The data from Meulaboh suggests that this rapid sedimentation has continued down the coast. As beaches provide a good form of tsunami protection the rapid beach recovery and the return of a large amount of sediment helps provide much needed coastal protection to the area.

Acknowledgements. This research was completed with funding from the London NERC DTP studentship NERC Grant Number NE/L002485/1.

\section{References}

1. Athukorala, P. and Resosudarmo, B. (2005) The Indian Ocean Tsunami: Economic Impact, Disaster Management, and Lessons. Asian Economic Papers, 1-39, 4(1)

2. Bristow, C. and Pucillo, K. (2006) Quantifying rates of coastal progradation from sediment volume using GPR and OSL: The Holocene fill of Guichen Bay, south-east South Australia. Sedimentology, 769-788, 53(4)

3. Choowong, M., Phantuwongraj, S., Charoentitirat, T., Chutakositkanon, V., Yumuang, S. and Charusiri, P (2009) Beach recovery after 2004 Indian Ocean tsunami from Phang-nga, Thailand. Geomorphology, 134-142, 104(3-4)

4. Engels, S, and Roberts, M. C. (2005) The Architecture of Prograding Sandy-Gravel Beach Ridges Formed During the Last Holocene Highstand: Southwestern British Columbia, Canada. Journal of Sedimentary Research, 75 (6): 1052-1064.

5. Gouramanis, C., Switzer, A., Polivka, P., Bristow, C., Jankaew, K., Dat, P., Pile, J., Rubin, C., Yingsin, L., Ildefonso, S. and Jol, H. (2015) Ground penetrating radar examination of thin tsunami beds - A case study from Phra Thong Island, Thailand. Sedimentary Geology. 149-165, 329

6. Grilli, S. T., Ioualalen, M., Asavanant, J., Shi, F., Kirby, J. T., and Watt, P. (2007) Source Constraints and Model Simulation of the December 26, 2004, Indian Ocean Tsunami. Journal of Waterway, Port, Coastal and Ocean Engineering, (2007), 414-428, 133(6)

7. Grzelak, K., Kotwicki, L. and Szczucinski, W. (2009) Monitoring of Sandy Beach Meiofaunal Assemblages and Sediments after the 2004 Tsunami in Thailand. Polish J. of Environ. Stud. Vol. 18, No. 1, 43-51

8. Hoang, V. C., Tanaka, H. and Mitobe, Y. (2019)Morphological recovery of beach severely damaged by the 2011 great east Japan tsunami. Esturine, Coastal and Shelf Science. 226

9. Ioualalen, M., Asavanant, J., Kaewbanjak, N., Grilli, S. T., J. T. and Watts, P. (2007) Modeling the
26 December 2004 Indian Ocean tsunami: Case study of impact in Thailand. Journal Of Geophysical Research, Vol. 112, C07024

10. Jol, H and Bristow, C. (2003) An introduction to ground penetrating radar (GPR) in sediments. Geological Society London Special Publications

11. Kendall, M. A., Aryuthaka, C., Chimonides, J., Daungnamon, D., Hills, J., Jittanoon, C., Komwachirapitak, P., Kongkaew, V., Mittermeyr, A., Monthum, Y., Nimsantijaroen, S., Paterson, G. L. J., Foster-Smith, R., Foster-Smith, J. and Thongsin, N. (2009) Post-Tsunami Recovery of Shallow Water Biota and Habitats on Thailand's Andaman Coast. Pol. J. Environ. Stud. 18(1):69-75

12. Knight, J. and Goff, J. R. (2016) Coastal science for post-tsunami reconstruction. Holocene, 1334-1340, 26(8)

13. Lee, V. J., Low, E. Ng, Y. Y. and Teo, C. (2005) Disaster Relief and Initial Response to the Earthquake and Tsunami in Meulaboh, Indonesia. Annals Academy of Medicine. Vol. 34 No. 9

14. Monecke, K., Finger, W., Klarer, D., Kongko, W., McAdoo, B., Moore, A. and Sudrajat, S. (2008) A 1,000-year sediment record of tsunami recurrence in northern Sumatra. Nature, 1232-1234, 455(7217)

15. Liew, C. S., Gupta, A., Wong, P. P. and Kwoh, L. K. (2009) Recovery from a large tsunami mapped over time: The Aceh coast, Sumatra

16. Meilianda, E., Dohmen-Janssen, C., Maathuis, B., Hulscher, S and Mulder, J. (2010) Short-term morphological responses and developments of Banda Aceh coast, Sumatra Island, Indonesia after the tsunami on 26 December 2004. Marine Geology, 96-109, 275(1-4)

17. Moore, A., Nishimura, Y., Gelfenbaum, G., Kamataki, T. and Triyono, R. (2004) Sedimentary deposits of the 26 December 2004 tsunami on the northwest coast of Aceh, Indonesia. Earth Planets Space. 253-258, 58.

18. Neal, A. (2004) Ground-penetrating radar and its use in sedimentology : principles, problems and progress. Earth-Science Reviews, , 261-330, 66

19. Neal, A. and Roberts, C. L. (2000) Applications of ground-penetrating radar (GPR) to sedimentological, geomorphological and geoarchaeological studies in coastal environments. Geological Society, London, Special Publications, 175, 139-171

20. Neal, A., Pontee, N.,Pye, K and Richards, J. (2002) Internal structure of mixed-sand-and-gravel beach deposits revealed using ground-penetrating radar. Sedimentology. 789-804, 49(4)

21. Paris, R., Wassmer, P., Sartohadi, J., Lavigne, F., Barthomeuf, B., Desgages, E., Grancher, D., Baumert, P., Vautier, F., Brunstein, D. and Gomez, C. (2009) Geomorphology Tsunamis as geomorphic crises : Lessons from the December 26 , 2004 tsunami in Lhok Nga , West Banda Aceh (Sumatra , Indonesia). Geomorphology. 59-72, 104 (1-2)

22. Paris, R., Wassmer, P., Sartohadi, J., Lavigne, F., Barthomeuf, B., Desgages, E., Grancher, D., Baumert, P., Vautier, F., Brunstein, D. and Gomez, 
C. (2010) Boulder and fine sediment transport and deposition by the 2004 tsunami in Lhok Nga (western Banda Aceh, Sumatra, Indonesia ): A coupled offshore - onshore model. Marine Geology, 43-54, 268(1-4)

23. Switzer, A., Bristow, C. and Jones, B. (2006) Investigation of large-scale washover of a small barrier system on the southeast Australian coast using ground penetrating radar. Sedimentary Geology. 145-156. 183.

24. Tamura, T., Murakami, F., Nanayama., F., Watanabe, K. and Saito, Y. (2008) Groundpenetrating radar profiles of Holocene raised-beach deposits in the Kujukuri strand plain, Pacific coast of eastern Japan. Marine Geology. 11-27, 248 (1-2) 